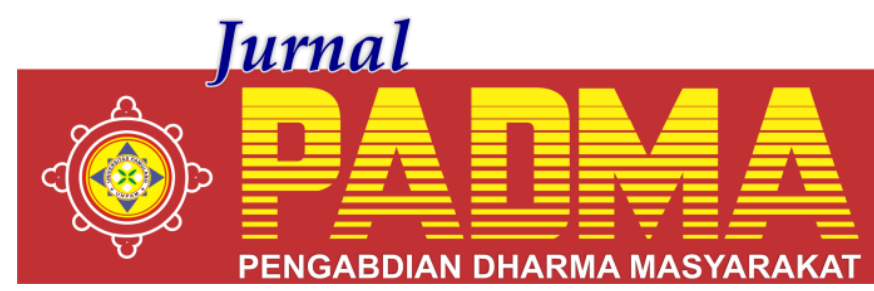

VOLUME I, NOMOR 3, JULI 2021

\title{
MENJADIKAN ONLINE SHOP SEBAGAI USAHA SAMPINGAN YANG MENJANJIKAN
}

\author{
${ }^{1 *}$ Tri Sulistyani, ${ }^{2}$ Yaya Uryanti, ${ }^{3}$ Dian Sari, ${ }^{4}$ Fitriyya Tawaqal, ${ }^{5}$ Hani Muawanah, \\ 6Linda Hermawati \\ Universitas Pamulang, Tangerang Selatan, Banten, Indonesia \\ *dosen01793@unpam.ac.id
}

\begin{abstract}
Abstrak
Tujuan Pengabdian Kepada Masyarakat (PKM) Mahasiswa ini adalah untukmemberikan pengetahuan dan pemahaman kepada Ibu PKK dan Posyandu di Kantor Desa Suka Asih yang beralamat di Jn. Bonana Permai - Teureup RT. 005 RW. 001 Desa Suka Asih,Kecamatan Pasar Kemis Kota Kabupaten Tangerang, sebagai wujud dari kegiatan Program Kreativitas Mahasiswa (PKM). Melalui proses kegiatan pengabdian kepada masyarakat yang dilakukan mampu menimbulkan semangat kembali pada para Ibu PKK dan Posyandu untuk berjual-belikan di media online shop atau toko online.
\end{abstract}

Kata Kunci: Online Shop

\section{Abstract}

The purpose of his student community service (PKM) is to provide knowladge and understanding to PKK and posyandu mothers at the Suka Asih Village Office which is located at Jl. Bonana Permai - Teureup RT 005.001 Suka Asih village, Pasar Kemis District, Tangerang City, as a from of student creativity progam (PKM) activity. Through the process of community service activities carried out, it is able tp incease enthusiasm to trede in online media stores or online shops

Keywords: Online Shops

\section{PENDAHULUAN}

Online shop atau bisnis online saat ini bukan lagi menjadi sesuatu yang asing bagi masyarakat Indonesia, baik yang dalam kesehariannya menggunakan internet ataupun tidak. Perkembangan bisnis secara online di Indonesia sekarang sangat pesat, salah satunya dengan melakukan belanja secara online. Belanja online merupakan salah satu cara berbelanja melaluialat komunikasi elektronik atau jejaring sosial yang digunakan dalam transaksi jual beli, di mana pembeli tidak perlu susah payah datang ke toko untuk melihat dan membeli apa yang mereka cari, hanya tinggal melihat barang yang diinginkan melalui internet kemudian memesan barang sesuai pilihan dan mentransfer uangnya dan kemudian barang tersebut akan dikirim oleh toko online tersebut kerumah.

Toko online merupakan bentuk perubahan yang di sajikan oleh internet dari segi inovasi dalam berbelanja dengan memberikan berbagai kemudahan dalam proses transaksinya. Belanja online memiliki beberapa keunggulan yang dapat dirasakan bagi pengguna konsumen. Disamping keunggulan yang kita rasakan ada beberapa ketidaknyamanan yang kita rasakan atau kelemahan dari online shop yang dirasakan. Alasan utama sebelumnya untuk belanja online adalah harga. Konsumen mempertimbangkan suatu harga saat akan membeli pada toko online, di mana persepsi harga seseorang akan mempengaruhi niat belanja seseorang. Kepercayaan konsumen dalam berbelanja online atau adalah kendala yang sulit untuk dikendalikan karena ada hubungannya dengan niat beli konsumen. Dalam merek merupakan kesan yang akan diterima oleh pelanggan dan konsumen yang dihasilkan dalam sebuahinterprestasi di pikiran mereka berdasarkan manfaatmanfaat emosional dan fungsional yang dirasakan. Kemudian faktor lain adalah orientasi belanja.

Terjadi pada persepsi harga, kepercayaan, orientasi merek dan orientasi belanja yang terbentuk akan mempengaruhi niat beli konsumen pada suatu produk. Niat beli adalah rencana kognitif atau keinginan konsumen untuk suatu barang 
atau merek tertentu. Terdapat pula perbedaan antara pembelian aktual dan kecenderungan pembelian.

\section{METODE}

Pengabdian kepada masyarakat ini dilakukan secara tatap muka (offline) dan mematuhi protokol Kesehatan sesuai dengan peraturan pemerintah yaitu 3M (Menjaga Jarak, Memakai Masker, dan Menghindari Kerumunan), karena dalam menghadapi masa pandemi Covid-19. Dengan mengacu pada peraturan pemerintah tersebut maka peserta dibatasi maksimal hanya 25 peserta dan peserta dibatasi selama 1 jam.

Kegiatan dilaksanakan dengan menyampaikan materi terkait menjadikan online shop sebagai usaha sampingan yang menjanjikan, menyusut tentang sejarah dan perkembangan online shop dan pelatihan penilaian meningkatan produk terhadap pasaran di toko online. Di akhir kegiatan diadakannya sesi tanya jawab/diskusi
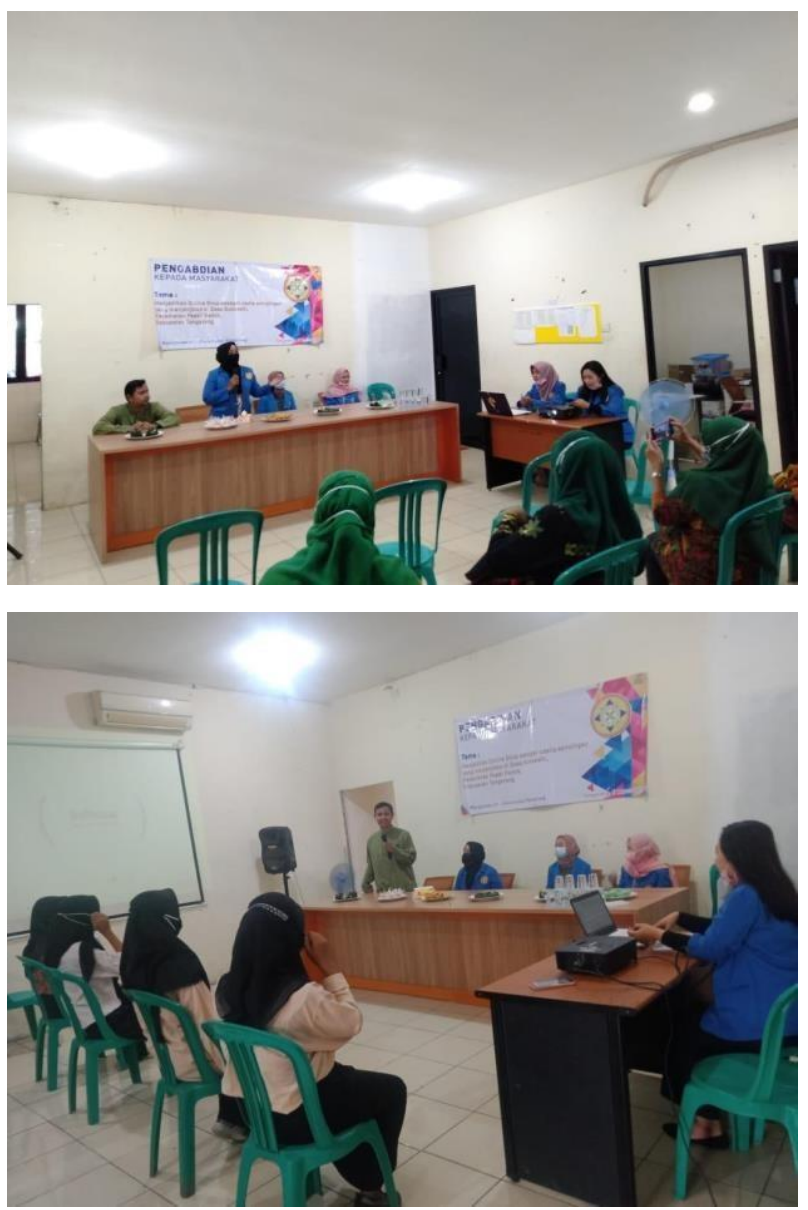

antara peserta dan narasumber (mahasiswa).

\section{HASIL DAN PEMBAHASAN}

Semenjak penggunaan online shop di Indonesia memang sangat menguntungkan bagi masyarakat terlebih lagi kita yang berada dalam keadaan pandemi yang mengakibat kita tidak dapat keluar rumah akibat covid-19 yang membuat kita harus melakukan sesuatu serba online. namun kita juga harus memperhatikan kerugian dalam onine shop sehingga kita dapat menjadipengguna sosial media yang baik dan bijak. Dengan pemaparan dan diskusi serta pelatihan memberi dorongan semangat untuk menumbuhkan kesadaran.

Kantor Desa bukan saja senangdidatangi, namun lebih dari itu sebagai sebuah bentuk kegiatan humanis yang sarat akan sentuhan kemanusiaan. Bagi civitas akademika (mahasiswa) khususnya dan bagi masyarakat umumnya. Dengan bersilaturahmi, berdiskusi, berdialog, ramah tamah, membangun relationship menjadi solusi terbangunnya semangat
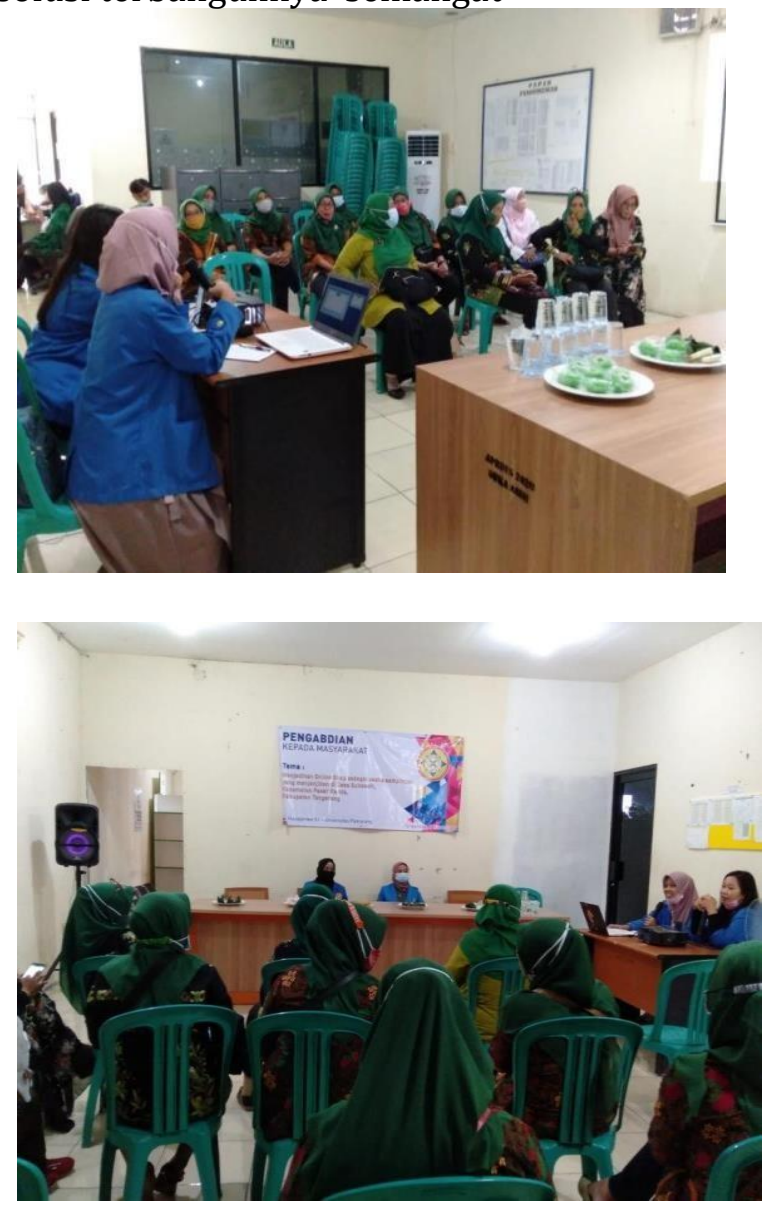

Gambar 2. Foto Kegiatan Pengabdian masyarakat (Sumber Dokumentasi) 


\section{PENUTUP}

Online shop adalah suatu proses pembelian barang atau jasa dari mereka yang menjual barang atau jasa melalui internet dimana antara penjual dan pembeli tidak pernah bertemu atau melakukan kontak secara fisik yang dimana barang yang diperjualbelikan ditawarkan melalui display dengan gambar yang ada di suatu website atau toko maya. Keberhasilan bisnis online di indonesia sangat dipengaruhi oleh faktor konsumen. Dari konsumen, ada dua hal yang paling ber pengaruh, yaitu orientasi transaksi dan kepercayaan.

Dari paparan yang telah disampaikan terkait pelaksanaan kegiatan PKM Mahasiswa Prodi Manajemen Universitas Pamulang, yang bertempat di Kantor Desa Suka Asih telah mendorong suasana kebersamaan dan semangat untuk bersosialisasi. Kerinduan masyarakat akan kehadiran dunia kampus tampak dalam pelaksanaan kegiatan tersebut.

\section{DAFTAR PUSTAKA}

Ajimat, A., Sunarsi, D., \& Sidiq, F. (2020). Berwirausaha Memanfaatkan Media Sosial Pada Daerah Sepatan. ADI Pengabdian Kepada Masyarakat, 1(1), 69-76.

Akbar, I. R., et al (2021). Peningkatan Minat Wirausaha Pada Siswa SMK Muhammadiyah Parung Kabupaten Bogor. Jurnal PADMA: Pengabdian Dharma Masyarakat, 1(2).

Dewanti, R. N., et al. (2021). Penyuluhan Dan Pelatihan Keterampilan Sablon Pigment Pasta Manual Di Karang Taruna 03 Desa Cisauk. Jurnal PADMA: Pengabdian Dharma Masyarakat, 1(1).

Erlangga, H. (2018). Spirit Pengembangan Kewirausahaan Di Perguruan Tinggi. Paradigma POLISTAAT: Jurnal Ilmu Sosial dan Ilmu Politik, 1(2), 102127.

Nurjaya, N., et al (2020). Pengaruh Store Atmosphere Terhadap Keputusan Pembelian Konsumen Pada Starbucks Di Wilayah Cianjur. Jurnal Ekonomi Efektif, 2(4), 637-643. 